\title{
IMPACT OF INTRAVAGINAL PROBIOTICS INOCULATION ON REPRODUCTIVE PERFORMANCE OF HOLSTEIN DAIRY CATTLE DURING TRANSITION PERIOD
}

\author{
EL-GARHI M.S. ${ }^{1}$ and N.E. EL-BORDENY ${ }^{2}$ \\ ${ }^{1}$ Animal Reproduction Research Institute, Agricultural Research Center, Giza, Egypt \\ ${ }^{2}$ Department of Animal Production, Faculty of Agric., Ain Shams Univ., P.O. Box 68 Hadayek Shoubra, 11241,
} Cairo, Egypt.

Received: 9 June 2019; Accepted: 30 July 2019

\begin{abstract}
In this study we tested the hypothesis that intravaginal infusions of lactic acid bacteria (LAB) around calving would improve uterine involution and reproductive performance of dairy cows. The probiotic culture used in this study was a mixture of $2 \mathrm{LAB}$ strains isolated previously from the vaginal tract of healthy pregnant heifers. Forty pregnant $2^{\text {nd }}$ lactation dairy cows 2 wk before the expected day of calving were assigned to one of 2 groups, first group was the control group (C) receiving $1 \mathrm{~mL}$ of media only, and the $2^{\text {nd }}$ group was the treated group $(\mathrm{T})$ receiving $1 \mathrm{~mL}$ of media enriched with probiotic bacteria at $10^{10}$ to $10^{12} \mathrm{cfu} /$ treatment. Intravaginal infusions were performed once during wk $-2,-1,+1,+2,+3$, and +4 relative to parturition with probiotic bacteria. All cows were observed for reproductive performance and reproductive diseases until next conception using ultrasonography. The incidence of uterine infections in the multiparous cows were measured. Days open, conception rate at $1^{\text {st }}, 2^{\text {nd }}$ and $3^{\text {rd }}$ insemination and repeat breeders $(\%)$ were calculated. Incidence of purulent and foul-smelling discharges on $+1,+2,+3$ and +4 wk relative to parturition and numbers of cows in the cleanup program were measured, cervix diameters (C.D) and uterine horn diameters (U.H.D) were measured at days (22-29) and days (38-45) postpartum. Ovarian structures and endometritis were determined. Results revealed that uterine and cervical involution of postpartum dairy cows were earlier in cows treated with LAB. Cows showed purulent and fowl smelling discharges are fewer in number in treated group than control, also data showed that percentage of cows in the cleanup program was higher in the control group (40\%) than in the treated group $(20 \%)$. The averaged insemination number per conception was lesser in the treated group (2.55) than control (4). The conception rate at $1^{\text {st }}$ insemination and $3^{\text {rd }}$ insemination was higher in the treated group $(35 \%, 20 \%)$ than in control one $(25 \%, 10 \%)$, and the \%of repeated breeder cows was lower in the treated group (30\%) than control (40\%), finally days open in the treated group (116.4) was much lower than in the control (154.72). Therefore it can be conclude that, intravaginal treatment of transition dairy cows with a mixture of lactic acid bacteria (LAB) could improve uterine involution, lower the incidence rates of uterine infections, and improve the reproductive performance.
\end{abstract}

Key words: Reproductive performance, uterine involution, Probiotics, Dairy cattle

\section{INTRODUCTION}

Transition dairy cows are susceptible to uterine infections due to the compromised immunity around calving and substantial bacterial contamination in the uterus immediately after calving. Uterine infections affect 1 in 2 dairy cows after parturition, infertility related to uterine infections has become the main raison for a cow to be culled from the herd (Rajala-Schultz and Gröhn, 1999). So far, there have been no effective approaches to treat uterine infections.

Corresponding author: Dr. EL-GARHI M.S.

E-mail address: m_elgarhi2005@yahoo.com

Present address: Animal Reproduction Research Institute,

Agricultural Research Center, Giza, Egypt.
The vaginal tract of dairy cows harbors various bacteria including aerobic, facultative anaerobic, and obligatory anaerobic ones (Wang et al., 2013). Plate culture analysis has shown that 15 Enterococcus and Staphylococcus are the predominant bacteria of the vaginal tract of healthy heifers, followed by Enterobacteriaceae and Lactobacilli (Otero et al., 2000). During gestation, the cervix is closed with a mucus plug, isolating the bacteria harboring vagina and the sterile uterine body. After parturition, the cervix is open to allow the drainage of intrauterine fluid, which also provides a passage for bacteria to ascend into the uterine body via the vaginal tract.

To our knowledge, there is no known effective treatments or prophylactic medications against uterine infections. Although various intrauterine antibiotics such as oxytetracycline ${ }^{\circledR}$ and cephapirin benzathine ${ }^{\circledR}$ are currently used to treat cows, their 
efficiency is not proven and concerns about drug residue in milk and carcass, or bacterial acquisition of drug-resistance have limited their widespread use (Galvão, 2011). Presently, there are no intrauterine antibiotics approved for utilization in dairy cows in the U.S (Galvão, 2011). Only systemic ceftifur® is approved for treatment of cows with metritis. Although systemic administration of ceftifur ${ }^{\circledR}$ could lower the incidence of metritis, it does not improve the reproductive performance (Risco and Hernandez, 2003).

Infusion of povidone iodine ${ }^{\circledR}$ also has been stopped due to its ineffectiveness, impeding of phagocytic activity of leukocytes in the uterus and triggering of endometrial necrosis (Azawi, 2008).

Intramuscular PGF2 $\alpha$ has been reported as a promising therapy in treating endometritis cows. It has a direct effect on flushing out bacteria from the uterus by stimulating myometrial contractions and enhancing immune responses (Lewis, 2003). However, a meta-analysis to previous studies demonstrated only a marginal benefit of PGF $2 \alpha$ on reproductive performance (Burton and Lean, 1995).

Recently, there is an increasing interest of using lactic acid bacteria (LAB) or probiotics to treat vaginal inflammatory conditions (Reid and Bruce, 2003; Ametaj et al., 2014). Nader-Macías et al. (2008) found that LAB strains isolated from vaginal tract have a strong capability of producing $\mathrm{H} 2 \mathrm{O} 2$. $\mathrm{H} 2 \mathrm{O} 2$-generating lactobacilli from the vaginal tract of cattle have the potential to be utilized as probiotics, among which Lactobacillus gasseri CRL1421 is reported to have the greatest capacity to inhibit Staphylococcus aureus by generating H2O2 and lactic acid (Otero and Nader-Macías, 2006). A few strains of LAB (mainly Lactobacillus fermentum) isolated from cow's vaginal mucus have been reported to be able to inhibit the growth of Actinomyces pyrogens in vitro, a recognized pathogen isolated from matristic cows, which hold great potential to be used as probiotic product to prevent metritis (Otero et al., 2006). Pediococcus acidilactici isolated from healthy pregnant dairy cows has exhibited inhibitory effect on Lactobacillus innocua and Enterococcus faecalis by the production of pediocin (Wang et al., 2013). A previous study reported that 6 times treatment around calving with a cocktail of $3 \mathrm{LAB}$, isolated from the vaginal tract of healthy cows, lowered the incidence of purulent vaginal discharges and improved conception rates of multiparous cows (Ametaj et al., 2014), they hypothesized that lowering the number of treatments around calving from 6 times to 2 or 3 treatments might give the same beneficial effects to the cows. Therefore the objectives of this study were to test whether intravaginal treatment of transition dairy cows with a mixture of lactic acid bacteria (LAB) can lower the incidence rates of uterine infections, improve uterine involution and improve the reproductive performance.

\section{MATERIALS AND METHODS}

Vaginal samples were obtained from pregnant Holstein heifers from Sanad farm (on Cairo-Ismailia desert road). The animals that had no history of metritis infection were selected. The vulvar area was washed with povidone-iodine and water. A disposable speculum was inserted into the vagina to swab the posterior area. Samples were collected and transported to the microbiology laboratory of Ain Shams University.

\section{Microbial strains and growth condition of the used probiotics}

Three isolates were isolated from vagina of pregnant Holstein heifers revealed on 2 bacterial strains characterized and identified to be propagated and used as a probiotic supplementation. Lactobacilli isolates were grown on MRS broth (Oxoid) while Streptococci isolates were grown on M17 broth (Difco), after that the broth media incubated for $24 \mathrm{~h}$ at $37{ }^{\circ} \mathrm{C}$. The strains were activated two or three times in order to obtain high biomasses in the stationary phase.

\section{Genetic identification of isolated and tested strains}

The isolates were identified according to 16sRNA in Sigma Company (Germany) by the automated sequencer (Table 1).

Table 1: The genetic identification of the tested probiotics stains.

\begin{tabular}{lcc}
\hline Probiotic strain & Isolation source & Isolation media \\
\hline Lactobacillus farraginis strain NRIC 0676 & & MRS \\
16S ribosomal RNA gene, partial sequence, NR & Pregnant heifers vaginal mucous & \\
041467.1 & & \\
\hline
\end{tabular}




\section{Experimental animals and design}

The probiotic culture used in this study was a mixture of $2 \mathrm{LAB}$ strains isolated previously from the vaginal tract of healthy pregnant heifers. Forty pregnant $2^{\text {nd }}$ lactation dairy cows 2 wk before the expected day of calving were assigned to one of 2 groups, $1^{\text {st }}$ group was the control group (20 cows) receiving $1 \mathrm{~mL}$ of media only, and the 2 nd group was the treated group (20 cows) receiving $1 \mathrm{~mL}$ of media enriched with probiotic bacteria at $10^{10}$ to $10^{12}$ cfu / treatment. The LAB infused in the vagina of the treated cows in our experiment are commensal bacteria identified and isolated from healthy vaginal tracts of pregnant heifers as previously described by Wang et al. (2013) and Ametaj et al. (2014). Intravaginal probiotics infusions were performed once per week during wk $-2,-1,+1,+2,+3$, and +4 relative to parturition. All cows were observed for reproductive performance and reproductive diseases until next conception. The incidence of uterine infections in the multiparous cows were measured. Days open, conception rate at $1^{\text {st }}, 2^{\text {nd }}$ and $3^{\text {rd }}$ insemination and repeat breeders $\%$ were calculated. Incidence of purulent and foul-smelling discharges on $+1,+2,+3$ and +4 wk were measured, cervix diameters and uterine horn diameters were measured in days (22-29) and (38-45) post-partum. The numbers of cows in the clean-up program were measured. Ovarian structures and endometritis were determined.

Research was conducted at Sanad farm. Animals used in this experiment were kept in the same conditions of housing. All cows were in the $2^{\text {nd }}$ parity, data about age, health condition and reproduction have been taken from farm protocol.

\section{Ultrasound examination}

Done by Unit of Radiology and Ultrasonography, Animal Reproduction Research Institute. Ultrasound scanning for reproduction have been performed starting from 22 to 45 days postpartum through two periods. First period was $22-29$ days, $2^{\text {nd }}$ was $38-45$ days postpartum. In this study it is been used diagnostic ultrasound electronic linear scanner. Examination technique is similar to standard transrectal manual examination. After removing feces from the rectum, we placed probe intra-rectally to obtain image of the uterus using portable, battery operated and B-mode ultrasound scanner. To obtain data of uterine horn diameter and cervix diameter, we have used, freeze“ mode and after that „caliper“ option at the edges of viewed tissues to get precise data about searched uterine dimensions. Obtained data about tissue dimensions were calculated. A Sonosite ultrasound (Sonosite, M- turbo, USA) fitted with (5-10)-MHz, L52x linear-array probe was used to obtain images of the cervix, uterine body and horns, follicles, and corpora lutea on ovaries of all cows according to (Melendez et al., 2004).

\section{Statistical analysis}

The various data were subjected to ANOVA procedure for a complete randomized design and performed according to Snedecor and Cochran (1982). Analysis of variance, by Duncan's test using, and least significant difference were applied to the data to test for differences between treatments using a computer program 'COSTAT', Significance was declared at $\mathrm{P}=0.05$. A trend was considered to exist if $0.05<\mathrm{P}<0.10$.

\section{RESULTS}

\section{Incidence of purulent and/or fowl smelling discharges}

Results showed that, cows showed purulent and fowl smelling discharges are fewer in no. in treated group than control, although no. of cows showed difficult labor and/or retained placenta was higher in the treated group (Table 2).

Table 2: Incidence of purulent or fowl smelling discharges

\begin{tabular}{lcccc}
\hline Group & Total cows no. & $\begin{array}{c}\text { No. of cows showed } \\
\text { dystocia and/or } \\
\text { retained placenta }\end{array}$ & $\begin{array}{c}\text { No of cows with } \\
\text { purulent and /or fowl } \\
\text { smelling discharges }\end{array}$ & $\begin{array}{c}\text { Incidence of purulent } \\
\text { and/or fowl smelling } \\
\text { discharges }\end{array}$ \\
\hline Control & 20 & 2 & 12 & $60 \%$ \\
\hline Treatment & 20 & 4 & 4 & $20 \%$ \\
\hline
\end{tabular}

\section{Ultrasound scanning for reproductive tract (22- 29 day postpartum)}

The results showed that, the cervical diameter, right horn and lift horn diameter decreased in the treated group than control, statistically there is no significant differences between treatment and control $(\mathrm{P}<0.05)$, only the average of cervix diameter tend to be significantly $(\mathrm{P}<0.09)$ lesser in the treated group than control. Cows in treated group showed lower percent of endometritis and pyometra than control group (table 3 and figure 3 ). 
Table 3: Ultrasound scanning for reproductive tract (22-29 day postpartum)

\begin{tabular}{lccccccc}
\hline Group & $\begin{array}{c}\text { Cervix } \\
\text { diameter } \\
\text { (average) } \\
\text { Cm } \\
\text { Mean } \pm \text { SD }\end{array}$ & $\begin{array}{c}\text { Right horn } \\
\text { diameter } \\
\text { (Average) } \\
\text { Cm } \\
\text { Mean } \pm \text { SD }\end{array}$ & $\begin{array}{c}\text { Lift horn } \\
\text { diameter } \\
\text { Average) } \\
\text { Cm } \\
\text { Mean } \pm \text { SD }\end{array}$ & $\begin{array}{c}\text { Cows showed } \\
\text { endometritis } \\
(\text { E. })\end{array}$ & $\begin{array}{c}\text { \% of } \\
\text { endometritis }\end{array}$ & $\begin{array}{c}\text { Cows showed } \\
\text { pyometra }\end{array}$ & $\begin{array}{c}\% \text { of Cows } \\
\text { showed } \\
\text { pyometra }\end{array}$ \\
\hline Control & $3.67 \pm 0.45$ & $3.2 \pm 1.8$ & $3.08 \pm 1.91$ & $6 / 19$ & 31.6 & 1 & 5.26 \\
\hline Treatment & $3.41 \pm 0.43$ & $2.53 \pm 0.48$ & $2.54 \pm 0.39$ & $1 / 16$ & 6.25 & 0 & 0 \\
\hline Sign. & 0.09 & 0.16 & 0.27 & - & - & - & - \\
\hline
\end{tabular}

Ultrasound scanning for reproductive tract $(38$ -

\section{5 day postpartum)}

Results showed that the cervical diameter, right horn and lift horn diameter were decreased in the treated group than control, statistically, there is no significant differences among treatments $(\mathrm{P}<0.05)$, also treated group showed lower percent of endometritis, pyometra and ovarian cysts than control (Table 4, figure 1 and 2).

Table 4: Ultrasound scanning for reproductive tract (38-45 day postpartum)

\begin{tabular}{|c|c|c|c|c|c|c|c|c|c|}
\hline Group & $\begin{array}{c}\text { Cervix } \\
\text { diameter } \\
\text { (average) } \\
\text { Cm } \\
(\mathrm{Mean} \pm \mathrm{SD})\end{array}$ & $\begin{array}{c}\text { Right horn } \\
\text { diameter } \\
\text { (Average) } \\
\text { Cm } \\
\text { (Mean } \pm \text { SD) }\end{array}$ & $\begin{array}{c}\text { Lift horn } \\
\text { diameter } \\
\text { (Average) } \\
\text { Cm } \\
\text { (Mean } \pm \text { SD) }\end{array}$ & $\begin{array}{c}\text { Cows } \\
\text { showed } \\
\text { endometritis } \\
\text { ( E ) }\end{array}$ & $\begin{array}{c}\% \text { of } \\
\text { Endometritis }\end{array}$ & $\begin{array}{c}\text { Cows } \\
\text { showed } \\
\text { pyometra }\end{array}$ & $\begin{array}{c}\% \text { of } \\
\text { pyometra }\end{array}$ & $\begin{array}{c}\text { Ovarian } \\
\text { cyst }\end{array}$ & $\begin{array}{c}\% \text { of } \\
\text { Ovarian } \\
\text { cyst }\end{array}$ \\
\hline Control & $3.6 \pm 0.55$ & $2.91 \pm 1.168$ & $2.77 \pm 1.91$ & $5 / 17$ & $29.4 \%$ & $1 / 17$ & $0.06 \%$ & $2 / 17$ & $1.2 \%$ \\
\hline Treatment & $3.31 \pm 0.49$ & $2.54 \pm 0.48$ & $2.33 \pm 0.39$ & $2 / 16$ & $12.5 \%$ & 0 & $0 \%$ & 0 & $0 \%$ \\
\hline Sign. & 0.16 & 0.22 & 0.27 & - & - & - & - & - & - \\
\hline
\end{tabular}

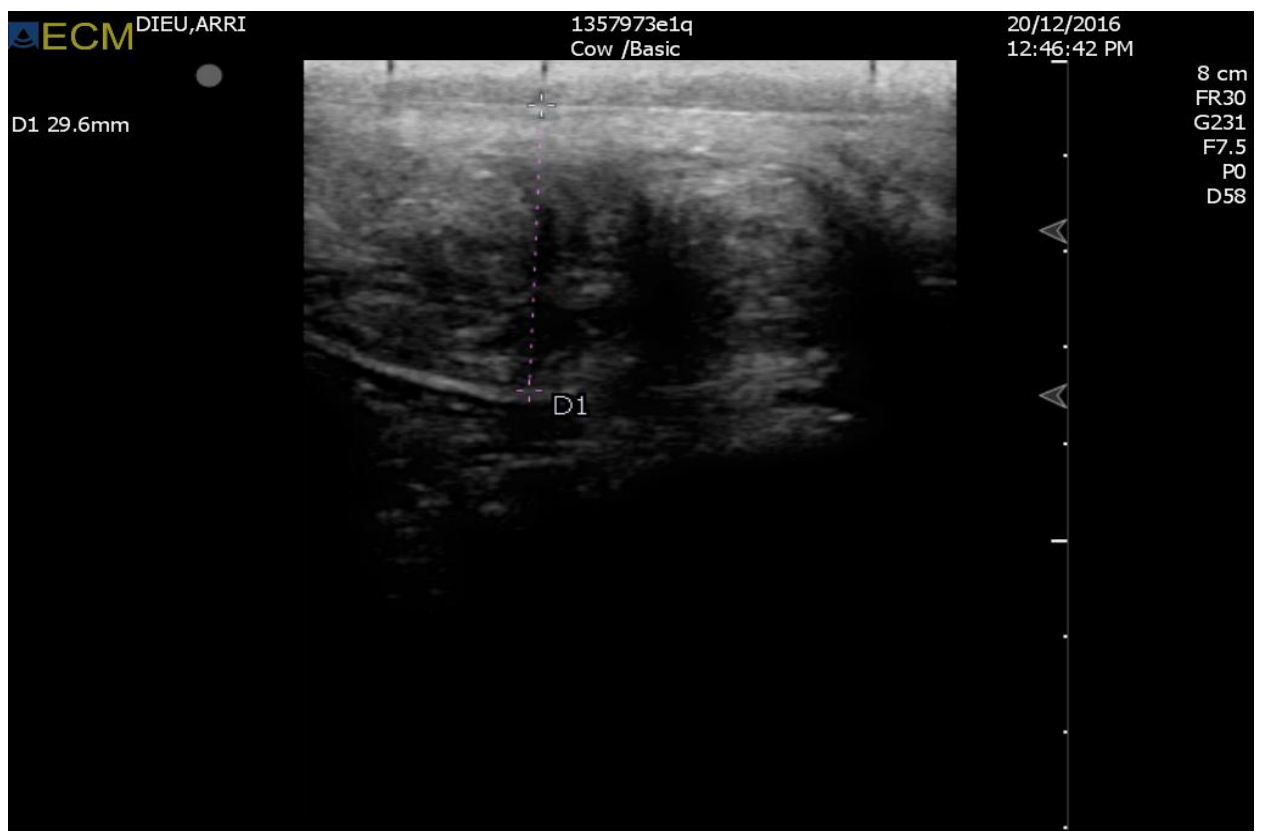

Figure 1: Ultrasound image showing cervix diameter (38-45 days postpartum) 


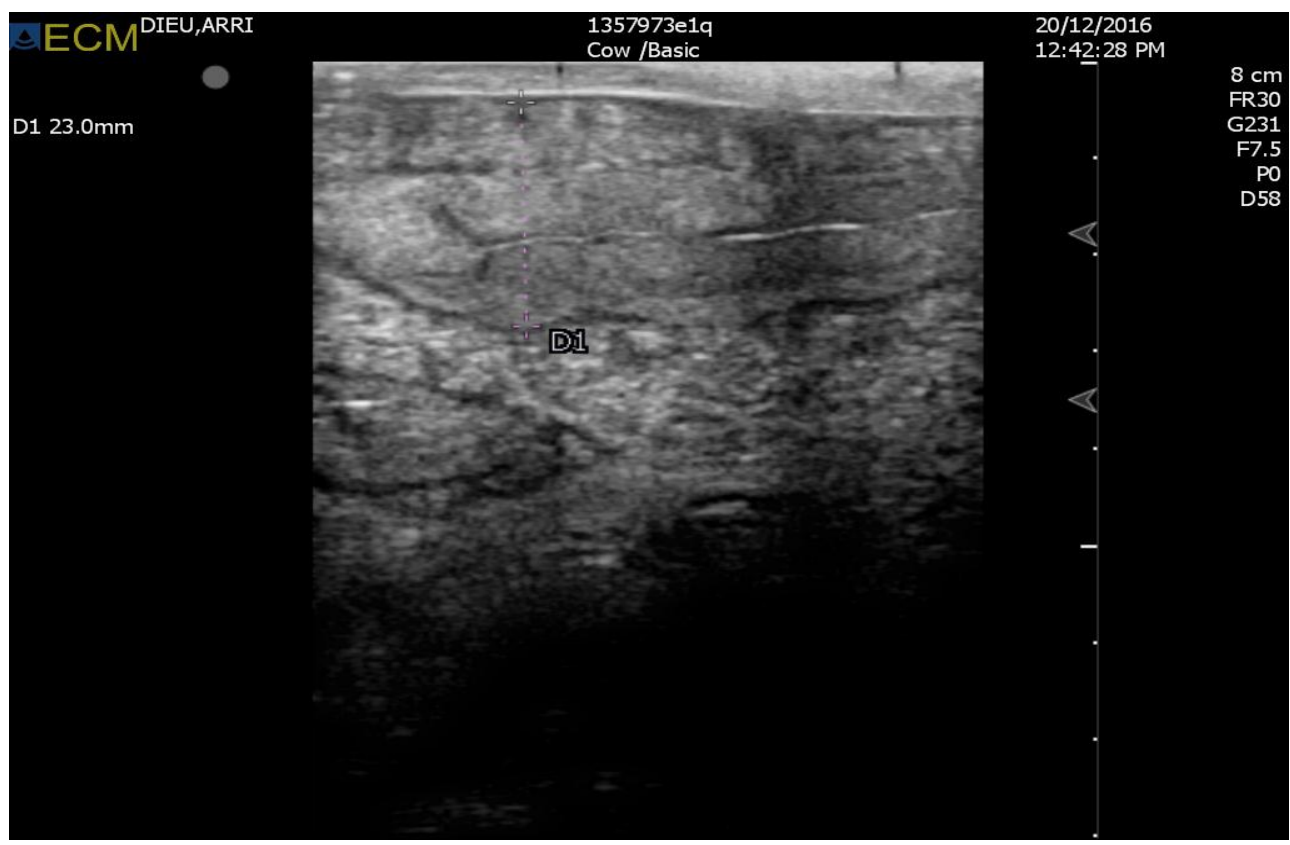

Figure 2: Ultrasound image showing endometritis (38-45 days postpartum)

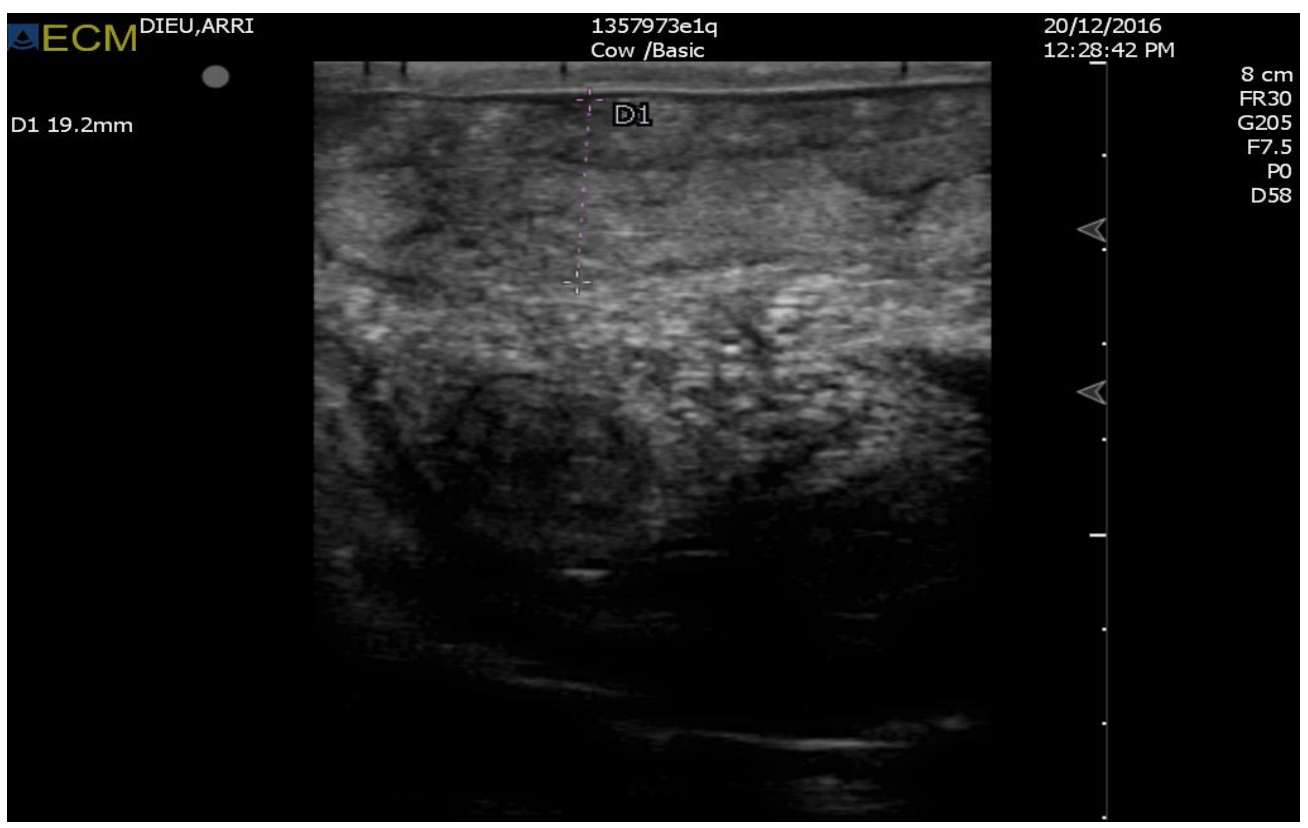

Figure 3: Ultrasound image showing uterine horn diameter of normal uterus (22-29 days postpartum)

\section{Reproductive parameters}

Results showed that percentage of cows in the cleanup program was higher in the control group $(40 \%)$ than in the treated group $(20 \%)$, the averaged insemination no. per conception was decreased in the treated group (2.55) than control, conception rate at $1^{\text {st }}$ insemination and $3^{\text {rd }}$ insemination was higher in the treated group $(35 \%, 20 \%)$ than control $(25 \%$, $10 \%)$, the no. of repeat breeder cows was lower in the treated group (30\%) than control (40\%), finally, days open in the treated group (116.4) was much lower than in the control group (154.72) with no significant $(\mathrm{P}<0.05)$ between the two groups as shown in table 5. 
Table 5: Effect of intravaginal probiotics inoculation on reproductive performance

\begin{tabular}{lccccccc}
\hline Group & $\begin{array}{c}\text { No of cows } \\
\text { in the } \\
\text { cleanup } \\
\text { program } \\
\text { before } 1^{\text {st }} \\
\text { insem. }\end{array}$ & $\begin{array}{c}\text { No of } \\
\text { insem. } \\
\text { /conception }\end{array}$ & $\begin{array}{c}\text { Conception } \\
\text { rate at } 1^{\text {st }} \\
\text { insem. }\end{array}$ & $\begin{array}{c}\text { Conception } \\
\text { rate at } 2^{\text {nd }} \\
\text { insem. }\end{array}$ & $\begin{array}{c}\text { Conception } \\
\text { rate at } 3^{\text {rd }} \\
\text { insem. }\end{array}$ & $\begin{array}{c}\text { \% of repeat } \\
\text { breeders } \\
\text { (more than 3 } \\
\text { insemination } \\
\text { /conception }\end{array}$ & Deans open \\
\hline Control & $8 / 20(40 \%)$ & 4 & $25 \%$ & $25 \%$ & $10 \%$ & $8 / 20(40 \%)$ & $\begin{array}{c}154.72 \pm 138 \\
(15 \text { cows })\end{array}$ \\
\hline Treatment & $4 / 20(20 \%)$ & 2.55 & $35 \%$ & $15 \%$ & $20 \%$ & $6 / 20(30 \%)$ & $116.4 \pm 42.13$ \\
$(20$ cows $)$
\end{tabular}

\section{DISCUSSION}

The results of this study revealed that intravaginal administration of LAB confers a health benefit to the reproductive tract against bacterial infections of dairy cows, results revealed that cows showed purulent and fowl smelling discharges were fewer in number in treated group than control, also the percentage of cows in the cleanup program was higher in the control group (40\%) than in the treated group (20\%), although number of cows showed difficult labor or retained placenta was higher in the treated group which refers to the prophylactic and treatment effect of the used vaginal probiotics. These results agreed with a previous study reported that 6 doses around calving with a cocktail of 3 LAB isolated from the vaginal tract of healthy cows lowered the incidence of purulent vaginal discharge of multiparous cows (Ametaj et al., 2014).

According to (Williams et al., 1995) time interval from parturition to the end of involution lasts 23 42 days. In the same study it was found that the greatest number of cows $(51,4 \%)$ completed involution during period from 29 to 35 days postpartum. The most intensive involution changes are developing up to 25 days postpartum, when uterine horn diameter is $20-40 \mathrm{~mm}$ and both horns are approximately same size (Leslie 1983), In research of Leslie (Leslie 1983) uterine involution in nursing cows has ended already after 15-25 days postpartum. In this study greatest number of cows has ended uterine involution in time period from 22 29 days. Results in table 3 and 4 also declared that treated group had better reproductive involution than control although the non-significance shown between treatments. Cervical diameter, right horn and lift horn diameter decreased in the treated group than control which confirm earlier uterine involution in the treated group, also treated group showed lower percent of endometritis, ovarian cysts and pyometra which confirm the prophylactic and treatment effect of the used vaginal probiotics.

Bacterial infections of the uterus are commonly present in the postpartum dairy cows, which are associated with histological lesions and inflammation of the uterine tissue (Sheldon et al., 2006). The lower incidence rates of metritis and total uterine infections in the treated group obtained in this study confirm previous finding that intravaginal LAB lowers purulent vaginal discharges in the treated cows (Ametaj et al., 2014). Lactobacillus spp., such as L. rhamnosus GG, L. rhamnosus GR-1, L. fermentum RC-14, and L. acidophilus are wellknown for their ability to maintain and restore a normal vaginal microflora and therefore have been used to prevent and treat urogenital infections in women (Reid et al., 2001; Gardiner et al., 2002; Reid et al., 2003). Lactobacillus spp. has been administered directly in the vagina attenuating or treating symptoms of vaginal infections (Reid et al., 1995; Hilton et al., 1995). This treating effect can be explained that infusion of LAB in the vaginal tract of cows increased concentrations of $\operatorname{IgA}$ in the vaginal mucus. Secretory $\operatorname{IgA}(\operatorname{sg} A)$ is recognized as the most important mucosal immunoglobulin of mucosal tissues, there are reports demonstrating that commensal bacteria can stimulate the production of $\operatorname{Ig} \mathrm{A}$ with the involvement of local epithelial cells and dendritic cells (DCs) (Thomas and Versalovic, 2010). In addition, Boullier et al. (2009) found that sIgA was able to dampen the inflammation at mucosal tissues. The LAB-treated cows had greater concentrations of $\operatorname{sIgA}$ in the vaginal tract on wk 0 (immediately after calving), +1 and +2 . This was probably due to the invasion of pathogenic bacteria into the reproductive tract during this period, as Kaila et al. (1992) found that Lactobacillus could promote the development of sIgA specific-antibody producing cells and therefore enhance the secretion of local $\operatorname{sgA}$ in the presence of pathogenic bacteria. 
The averaged insemination no. per conception was lesser in the treated group than control, also treated group had better conception rate at $1^{\text {st }}$ insemination and $3^{\text {rd }}$ insemination than control group, these results were in agreement with (Ametaj et al., 2014) Who reported that 6 doses around calving with a cocktail of $3 \mathrm{LAB}$ isolated from the vaginal tract of healthy cows improved conception rates of multiparous cows. The no. of repeat breeder cows decreasd in the treated group than control, finally days open in the treated group was much lower than control and agreed with (Deng et al., 2015) who found that two doses vaginal infusion of $\mathrm{LAB}$ decreased the number of days from calving to conception than control by $40 \mathrm{~d}$ (110 vs. $150 \mathrm{~d})$.

\section{CONCLUSION}

It can be conclude that, intravaginal treatment of transition dairy cows with a mixture of lactic acid bacteria (LAB) can lower the incidence rates of uterine infections, improve uterine involution and improve the productivity of reproduction.

\section{ACKNOWLEDGMENT}

Authors would like to express their thankful to the science and Technology development fund (STDF), ministry of higher education study through national challenges' target project "production of probiotics and evaluation its impact on dairy and beef cattle performance, ID-10802".

\section{REFERENCES}

Ametaj, B.N.; Iqbal, S.; Selami, F.; Odhiambo, J.F. and Wang, $Y$. et al. (2014): Intravaginal administration of lactic acid bacteria modulated the incidence of purulent vaginal discharges, plasma haptoglobin concentrations, and milk production in dairy cows. Res. Vet. Sci. 96: 365-370.

Azawi, O.I. (2008): Postpartum uterine infection in cattle. Anim. Reprod. Sci. 105:187-208.

Boullier, S.; Tanguy, M.; Khalil, A.K.; Caubet, C. and Sansonetti, P. et al. (2009): Secretory IgA-mediated neutralization of Shigella flexneri prevents intestinal tissue destruction by down-regulating inflammatory circuits. J. Immunol. 183:5879-5885.

Burton, N.R. and Lean, I.J. (1995): Investigation by meta-analysis of the effect of prostaglandin F $2 \alpha$ administered postpartum on the reproductive performance of dairy cattle. Vet. Rec. 136: 90-94.

Deng, Q.; Odhiambo, JF.; Farooq, U.; Lam, T.; Dunn, SM. and Ametaj, BN. (2015): Intravaginal lactic acid bacteria modulated local and systemic immune responses and lowered the incidence of uterine infections in periparturient dairy cows. PLoS ONE 10:e124167. doi: 10.1371/journal. pone. 0124167

Galvão, K.N. (2011): Identifying and treating uterine disease in dairy cows. Pages 21-29 in Proc. 47th Florida Dairy Production Conference, Gainesville, FL.

Gardiner, G.E.; Heinemann, C.; Bruce, A.W.; Beuerman, D. and Reid, G. (2002): Persistence of Lactobacillus fermentum RC14 and Lactobacillus rhamnosus GR-1 but not L. rhamnosus GG in the human vagina as demonstrated by randomly amplified polymorphic DNA. Clin. Diagn. Lab. Immunol. 9:92-96.

Hilton, E.; Rindos, P. and Isenberg, H.D. (1995): Lactobacillus GG vaginal suppositories and vaginitis. J. Clin. Microbiol. 33:1433.

Kaila, M.; Isolauri, E.; Soppi, E.; Virtanen, E. and Laine, S. et al. (1992): Enhancement of the circulating antibody secreting cell response in human diarrhea by a human Lactobacillus strain. Pediatr. Res. 32: 141-144.

Leslie, H.E. (1983): The events of normal and abnormal postpartum reproductive endocrinology and uterine involution. Canadian Veterinary Journal 24, 67-71.

Lewis, G.S. (2003): Steroidal regulation of uterine resistance to bacterial infection in livestock. Reprod. Biol. Endocrinol. 1:117-125.

Melendez, P.; McHale, J.; Bartolome, J.; Archbald, L.F. and Donovan, G.A. (2004): Uterine involution and fertility of Holstein cows subsequent to early postpartum PGF2 $\alpha$ treatment for acute puerperal metritis. J. Dairy Sci. 87:3238-3246.

Nader-Macías, M.E.; Otero, M.C.; Espeche, M.C. and Maldonado, N.C. (2008): Advances in the design of probiotic products for the prevention of major diseases in dairy cattle. $\mathbf{J}$. Ind. Microbiol. Biotechnol. 35: 1387-1395.

Otero, C.; Saavedra, L.; Silva, C.; Ruiz, De.; Wilde, O. and Holgado, A.R. et al. (2000): Vaginal bacterial microflora modifications during the growth of healthy cows. Lett. Appl. Microbiol. 31: 251-254.

Otero, M.C. and Nader-Macías, M.E. (2006): Inhibition of Staphylococcus aureus by H2O2-producing Lactobacillus gasseri isolated from the vaginal tract of cattle. Anim. Reprod. Sci. 96:35-46.

Otero, M.C.; Morelli, L. and Nader-Macías, M.E. (2006): Probiotic properties of vaginal lactic acid bacteria to prevent metritis in cattle. Lett. Appl. Microbiol. 43: 91-97.

Rajala-Schultz, P.J. and Gröhn, Y.T. (1999): Culling of dairy cows. Part I. Effects of diseases on culling in Finnish Ayrshire cows. In Preventive Veterinary Medicine, vol. 41, p. 195-208. 
Reid, G.; Bruce, A.W. and Taylor, W. (1995): Instillation of Lactobacillus and stimulation of indigenous organisms to prevent recurrence of urinary tract infections. Microecol. Ther. 23: 32-45

Reid, G. and Bruce, A.W. (2003): Urogenital infections in women: can probiotics help? Postgrad. Med. J. 79: 428-432.

Reid, G.; Beuerman, D.; Heinemann, C. and Bruce, A.W. (2001): Probiotic Lactobacillus dose required to restore and maintain a normal vaginal flora. FEMS. Immun. Med. Microbiol. 32:37-41.

Reid, G.; Charbonneau, D.; Erb, J.; Kochanowski, B. and Beuerman, D. et al. (2003): Oral use of Lactobacillus rhamnosus GR-1 and L. fermentum RC-14 significantly alters vaginal flora: randomized, placebo-controlled trial in 64 healthy women. FEMS Immunol Med Microbiol. 35:131-134.

Risco, C.A. and Hernandez, J. (2003): Comparison of ceftiofur hydrochloride and estradiol cypionate for metritis prevention and reproductive performance in dairy cows affected with retained fetal membranes. Theriogenology. 60:47-58.
Sheldon, I.M.; Lewis, G.S.; LeBlanc, S. and Gilbert, R.O. (2006): Defining postpartum 219 uterine disease in cattle. Theriogenology. 65: 15161530 .

Snedecor, G.W. and Cochran, W.C. (1982): Statistical method (7th Ed), Iowa Univ. Press, Iowa, USA.

Thomas, C.M. and Versalovic, J. (2010): Probioticshost communication: modulation of signaling pathways in the intestine. Gut Microbes. 1: 148-163.

Wang, Y.; Ametaj, B.N.; Ambrose, D.J. and Gänzle, M.G. (2013): Characterization of the bacterial microbiota of the vagina of dairy cows and isolation of pediocin producing Pediococcus acidilactici. BMC Microbiol. 13: 19-29.

Williams, E.J.; Fischer, D.P.; Noakes, D.E.; England, G.C.W.; Rycroft, A.; Zain, A.; ELDin.; Nakao, T.; Raouf, M.; Abdel, Moriyoshi, M.; Kawata, K. and Moritsu, Y. (1995): Factors in the resumption of ovarian activity and uterine involution in postpartum dairy cows. Animal reproduction science 38, 203-214.

\section{تأثير التلقيح المهبلي لبكتريا البروبيوتك على الاداء التناسلي لأبقار الهولثتين الحلابة}

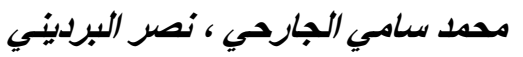

E-mail: m_elgarhi2005@yahoo.com

Assiut University web-site: www.aun.edu.eg

في هذه الدر اسة تم اختبار فرضية ما اذا كان استخدام بكتريا حمضض اللاكتيك مهبليا من الممكن ان يكون لها تاثير ايجابي على الاداء

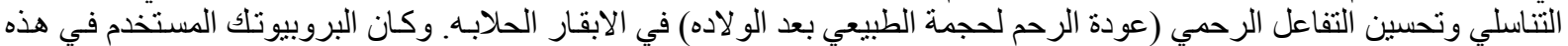

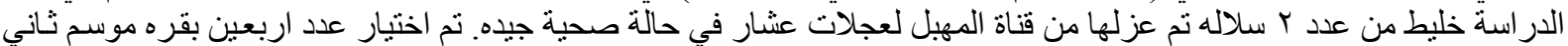
اسبو عين قبل مو عد الو لاده المنتظر ، وتم تقسيمهر عشو ائيا الى مجموعتين ، المجموعة الاولى كانت المجموعة الضابطه ( • ب بقره) ؛

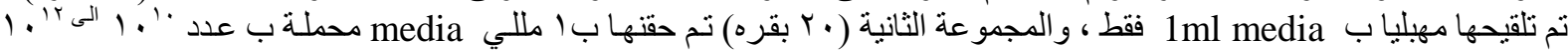

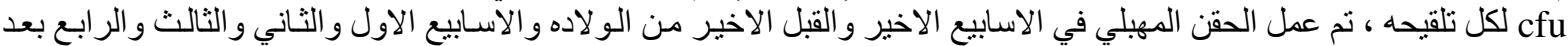

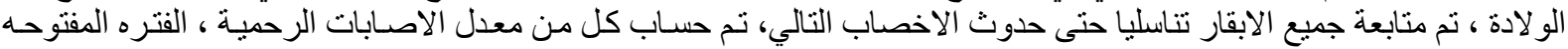

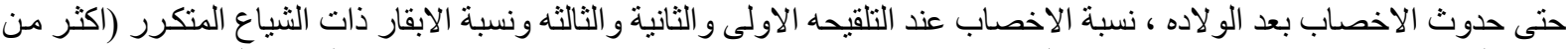

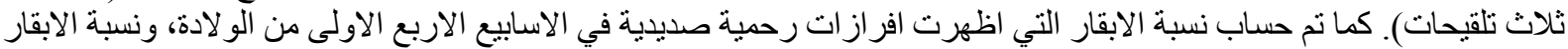

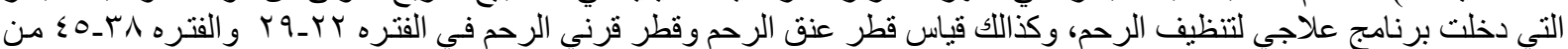

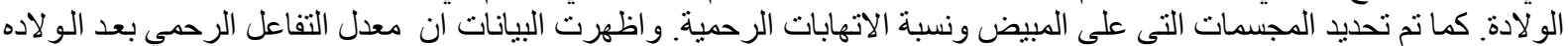

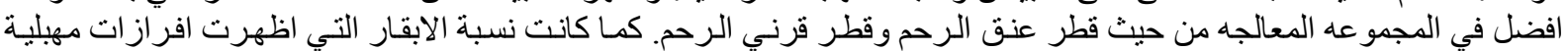

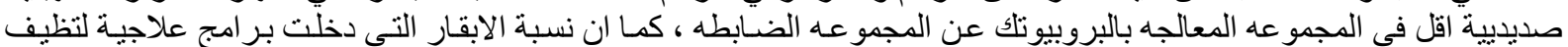

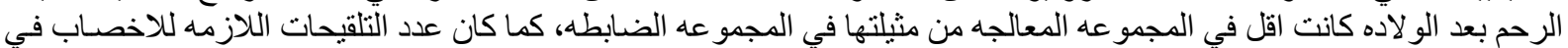

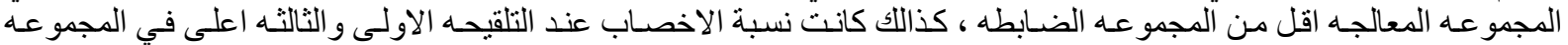

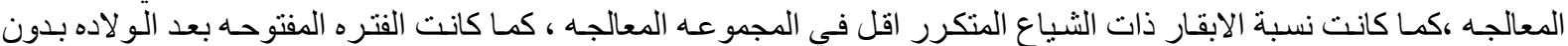

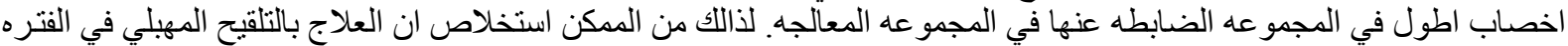

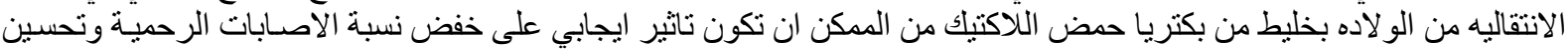
معدل التفاعل الرحمي ورفع معدل الخدم لخدية.

الكلمات الداله: الاداء التناسلي ، التفاعل الرحمي ، البروبيوتلك ، الابقار الحلابه 